\title{
A STUDY ON A VIRAL VIDEO ABOUT BULLYING A TEACHER
}

\author{
Kadek Intan Rustiana Dewi', Ni Putu Oksa Trisnadiani², Antonius Gita Adetian ${ }^{3}$ \\ Jurusan Pendidikan Bahasa Inggris, Fakultas Bahasa dan Seni \\ Universitas Pendidikan Ganesha \\ Jalan Jend. A. Yani 67 Singaraja 81116, Telp. 0362-21541, Fax. 0362-27561 \\ Email: gita.adetian@gmail.com ${ }^{3}$
}

\begin{abstract}
ABSTRAK
Artikel ini bertujuan untuk meneliti wacana yang terdapat dalam sebuah video. Video ini mengandung kontroversi yang berjudul "Tidak Sopan, Seorang Siswa SMK Negeri 3 Denpasar Bali Menanyakan Rumah Flyod Mayweather Kepada Guru" yang diunggah di YouTube pada 22 September 2017. Penelitian ini dimaksudkan guna menjawab tiga pokok permasalahan yang ditemukan dalam wacana. Adapun ketiga permasalahan tersebut yakni alasan di balik judul video yang menggunakan kata 'tidak sopan', motif siswa menanyakan rumah Mayweather, serta motif siswa memilih guru sebagai sasaran pertanyaan tersebut. Wacana ini dikaji dengan menggunakan pendekatan kualitatif yang didukung oleh beberapa teori, yakni teori kesopanan, teori norma, sor singgih basa Bali, teori prank, teori imitasi, serta teori hierarki. Hasil dari kajian wacana ini menunjukkan bahwa kata 'tidak sopan' sangat tepat digunakan pada judul video yang didasari oleh beberapa bukti yang ditemukan. Hasil kedua menunjukkan bahwa siswa tersebut memiliki tiga motif dalam menanyakan rumah Mayweather, yakni untuk melakukan prank, meniru orang lain, serta untuk memperoleh popularitas. Sementara, hasil akhir menunjukkan bahwa siswa tersebut memilih guru sebagai sasaran guna memperlihatkan kekuasaan dan kekuatan yang dimilikinya.
\end{abstract}

Kata kunci: video, bullying, tidak sopan, guru, siswa, prank

\section{ABSTRACT}

This article aims to investigate a discourse in the form of video. The video is a controversial one, entitled "Tidak Sopan, Seorang Siswa SMK Negeri 3 Denpasar Bali Menanyakan Rumah Flyod Mayweather Kepada Guru" uploaded on YouTube on September 22nd, 2017. The objective of this article is to answer three main problems found in the discourse. Those problems are about the reason behind the title of the video containing the word 'impolite', the motive behind asking the location of Mayweather's house, and the motive behind choosing teacher as the target of student's question. The discourse was analyzed by using qualitative approach supported by several theories, namely politeness theory, norms theory, sor singgih basa Bali, prank theory, imitation theory, and hierarchy theory. The results showed that the use of word 'impolite' in the title of the video is correct based on several evidences that the researchers found in the video. The second result showed that the student has three motives of asking the location of Mayweather's house, namely doing a prank, imitating other pranksters, and gaining fame. The last result showed that the motive of student in choosing teacher as the target is to show that he is more powerful than others.

Keywords: video, bullying, impolite, teacher, student, prank

\section{INTRODUCTION}

The relationship between teacher and students becomes a crucial aspect in education, especially in teaching and learning pro- cess. When the teacher and students build a good relationship, the teaching and learning process will run well and become effective. However, years by years, many phenomenons related to the bad relationship between teacher 
and students are discovered. The bad relationship that is meant here is the phenomenon in which teacher and student treat each other badly. In many phenomenons which have been discovered, teachers often treat their students badly by involving physical punishment. It cannot be denied that some teachers have spoken harshly to the students, hit or slap them, or even bullied them. However, it is not only teacher who treat their students badly. Many phenomenons showed that students also treat their teacher badly. Students disrespect their teacher, disobey their instruction, make fun of them, and even bully them.

The phenomenons in which students disrespect, make fun, or even bully their teacher have drawn the public's attention. It is because such phenomenon is getting worse. An article published in CNN entitled "Educators: Kids are not the only ones bullied" reported that teachers and school staff members were often bullied by students. A teacher was thrown an eraser, a school bus driver was jabbed, and other teachers were made fun by their own students during the class. A study which was conducted by The Canadian Teachers Federation showed that one third of teachers in Ontario have experienced the feeling of being bullied by their students. Similar thing also happened in Indonesia. As reported by Aditya (2016) in Tribun News, the number of students' misbehavior, especially disrespect and impoliteness towards teachers increases day by day. One popular case of students disrespect their teacher came from an elementary school student who spoke impolitely as he was given advice by his teacher. Another case was about a junior high school student who made fun of her teacher by giving impolite poses as she took pictures of her and the teacher. Similar cases reported by Aditya (2016) in Tribun News was about a senior high school student who showed a bad manner towards his teacher as he smoked right beside his teacher in the classroom and sat in a bad manner. Some of those cases were said to be a joke that is played by the students to the teacher. However, this case turned to be cases of disrespecting teacher that count as misbehavior.
As reported by CNN, students' misbehaviors, jokes, or pranks can lead them to a case of bullying. Regarding to this issue, this article aims to do a discourse analysis toward a similar case that happened recently in Indonesia, specifically in Bali. The discourse analysis will be conducted on a video about an interaction between teacher and student which is said containing a disrespect or impoliteness towards the teacher that may lead to bullying. In detail, the video is about a senior high school student who suddenly asked the location of Mayweather's house in the middle of a teaching and learning process. Regarding to this, this article attempts to analyze some points to clarify the issue, namely the reason behind writing the title which contained the word "impolite", the motives of student in asking Mayweather's house, and the motives behind the teacher that became the target of the video.

\section{REVIEW OF RELATED LITERATURE}

In conducting the analysis, six theories were used to support, strengthen, and prove the assumptions of the researchers. Those theories are politeness theory, norms theory, sor singgih basa Bali, prank theory, imitation theory, and hierarchy theory. The first one is politeness theory. First of all, polite can be defined as showing good manners to other people, as in behavior and speech (Oxford Dictionary). Meanwhile, in linguistics field, experts have proposed the definition of politeness. According to Brown and Levinson (1987), politeness is a strategy to make the interlocutor's face safe. Face in this case refers to someone's respect and self-esteem. Meanwhile, according to Nordquist (2017) politeness can be defined as speech acts that are used to show concern toward other people and decrease treats toward someone's self-esteem or face in certain social context.

Besides, norms theory is used in this research. According to Faridy (2009), norms are defined as rules used to direct and manage someone's manner and behavior. He further explains that norms provide human with the ways they should behave in society. Basical- 
ly, there are four norms applied in Indonesia based on Pancasila, namely moral norms, ethical norms, legal norms, and religious norms. Faridy (2009) explained those four norms in his book in which religious norms are derived from holy book, legal norms are established by the authorized institutions in a country, and then moral norms are derived from human's conscience. Meanwhile, ethical norms are the last norms explained by him. Ethical norms are derived from the culture of human itself. This norm has been accepted as guidance to manage one's behavior toward others since it is established from usual habit of society. Faridy (2009) states that ethical norm is related to the way of someone behaves and speaks appropriately in a society. He further said that people have to respect one another in their society, as in behavior and speech. He mentions several examples of the implementation of this norm, such as talking and behaving in a good manner, especially to someone who is older and has higher position.

Not only norms theory, but Sor singgih basa Bali also supports this research. Sor singgih basa Bali is defined as the classification of Balinese language based on its level of politeness (Adnyana, 2014). This term is also known as Anggah Ungguhin Basa Bali. It is officially accepted in Pesamuhan Agung (Loka Karya) Basa Bali in 1974 in Singaraja. Narayana (2014) in Adnyana (2014) states, the level of Balinese speakers will be reflected through the use of sor singgih basa Bali as their media of communication. Narayana (1984) as cited in Adnyana (2014) has classified sor singgih basa Bali into four based on its use in society, as the following:

a) Basa kasar is a classification of Balinese language which is impolite and commonly used when the speaker is angry. For example, tidik (eat), cang (I), nani (you), etc.

b) Basa andap is a classification of Balinese language which is considered as polite language if the participants of the speaking are in the equal position, age, and level of education. This classification, on the other hand, can be considered as impolite language if one of them, in this case the speaker, uses this lan- guage to speak with someone which has higher position than him/her. For example, umah (house), kal (will), pesu (go out), etc.

c) Basa madia is a classification of Balinese language in which its level of politeness is in the middle, between basa alus and basa andap. The words in this language only have one form in which they are not considered as polite nor impolite language. This language is used when the participants are not familiar with each other. For example, dija (where), gulem (gloomy), etc.

d) Basa alus is a classification of Balinese language which is considered as a very polite language. This language is commonly used in the formal situation, such as meeting, speech, or even religious ceremony. It is also used to speak with someone who has higher position than the speaker, as in age, level of education, or even social status. For example, marayunan (eat), griya/jero (house), titiang (I), jagi/lakar (will) etc.

Likewise, prank theory supports this research. Prank is a trick that is played on someone in which the intention is to be funny and not to cause harm or damage (Cambridge Dictionary, 2015). From the psychology theory, prank is intended to be done in a positive way in order to create laughter and to integrate with a new people and environment, but the wrong way of pranking can cause bullying and victim (Psychologypapers). Another psychology theory that underlies prank was proposed by Blockey in Williams (2016), a criminologist at the University of Derby. He stated that most of the prankster would be men, while the victim would be powerless women. This is a common pattern used by the prankster to show his dominant power and position. In other words, the pranksters want to show that they are more powerful than the victim. Blockey added that in doing the prank, the pranksters would show their power and control over the victim. They would be so proud and see this as an achievement, because they have power and are able to control other people. Another point explained by Blockey is about the prankster who never thinks that someone they play the trick on as the victim. They would only see 
them as the object of their achievement.

On the other hand, imitation theory also used to support this research. Imitation was proposed by Tarde in Roen (2011) explains that social interaction is based on the imitation process. It means that people tend to imitate their social environment in order to form their own behavior and ability. The imitation itself happens because of admiration towards what and who they will imitate. Because someone admires other people, they tend to imitate anything from what they admire. It can be about the behavior, life style, attitude, or even performance.

Lastly, hierarchy theory is used to strengthen the analysis. According to Maslow in Lisa (2013), hierarchy theory is a motivational theory in psychology consisting of five stages of human needs, namely psychological needs, safety needs, possession and love needs, self-esteem needs, and self-actualization needs. These stages of human needs depicted as a hierarchical pyramid. The lowest stages are psychological needs such as foods, water, warmth, rest, shelter and followed by safety needs, such as protection from elements, security, order, law, stability, and freedom from fear. Those needs belong to basic needs of human. Possession and love needs are related to intimate relationship and friendship, then followed by self-esteem need that is classified into two categories: (I) esteem for oneself e.g. dignity, achievement, mastery, independence, and (II) the desire for reputation or respect from others e.g. status, prestige. Maslow argues that the need for respect or reputation is most important for children and adolescents. It precedes real self-esteem or dignity and these belong to psychological needs. Generally, self-esteem needs stage is a stage where people freely do anything to fulfill their ego and the desire to have a prestige. Meanwhile, the highest stage of hierarchical pyramid is self-actualization which means a need to prove and show themselves to other people. This need involves a constant desire to fulfill their potential which is called selffulfillment needs. In this stage of hierarchical pyramid, someone will develop their po- tency as best as they can do to support them in showing and proving themselves. However, although all the lower needs such as psychological needs, safety needs, belongingness and love needs, and self-esteem needs are fulfilled, it does not mean that self-actualization will be fulfilled later. In other words, this need is a human needs that will never be fulfilled and satisfied.

\section{METHODOLOGY}

This analysis is a descriptive qualitative research in form of discourse analysis in which it analyzed more on the words than the numbers. The data would be investigated about what, why, and how the process of a phenomenon happened which cannot be explained by just measuring the frequency. The source of the data is a controversial video on YouTube which shows an interaction between a teacher and a student of SMK N 3 Denpasar during teaching and learning process. Researchers observed the use of language and used assumption supported by several theories to analyze the problems of this analysis. Politeness theory, norms theory, sor singgih basa Bali, prank theory, imitation theory, and hierarchy theory were used to analyze the data. Some related news were also used to analyze the problem statements of the analysis. Those theories and related news will help to analyze the research data in getting detail and complete explanation.

\section{RESULTS AND DISCUSSION}

\section{Why did the writer state the word 'impo- lite' in the title of the video?}

By considering some theories related to the issue above, researchers found that there are several reasons behind the use of the word 'impolite' as the title of the video. First of all, the real meaning of the word 'polite' was analyzed. As explained in the review of related literature, polite can be defined as showing good manners to other people, as in behavior and speech (Oxford Dictionary). On the other hand, Brown and Levinson (1987), de- 
fine politeness as a strategy to make the interlocutor's face safe. Meanwhile, according to Nordquist (2017), politeness can be defined as speech acts that are used to show concern toward other people and decrease treats toward someone's self-esteem or face in certain social context. From those definitions, researchers found that a student in the video is contrary to what were explained by the definitions of the word 'polite'. This finding was supported by other theory to make it more valid, namely norms theory. As what stated in norms theory, namely ethical norms, a person has to respect one another in society by behaving and talking in a good manner, especially to a person who has higher position than us. That student did not obey the ethical norms in which the way he talked was not in a good manner, even though at that time, he talked to a person who has higher position than him who is his teacher.

- First dialogue

Student: Bu, dije umah ne Mayweather, bu? (Ma'am, where is location of Mayweather's house?

Teacher: Apa?

(Sorry?)

Student: Mayweather. Ije umah ne?

(Mayweather. Where is his house?)

- Second dialogue

Student: Metakon umahne Mayweather ije.

(I am asking about where the location of Mayweather's house is)

Teacher: Yen kel pesu, pesu. Istirahvat, istirahat.

(If you want to go out, you can go out. Have your break time)

Student: Mula kel pesu.

(Of course, I will go out)

As what Suasta (1997) in Adnyana (2014) has classified, the use of words above are considered as Basa Bali Andap since the existence of the words 'umah' (house) in the first and second dialogue. Then, the words ' $k e l$ '(will) and 'pesu' (go out) also indicated that the student used Basa Bali Andap. Those words must be used when the speaker and the interlocutor have an equal position, as in age, status, or even level of education. However, in fact, the student was talking to his teacher who is older, has higher position, and has higher level of education than him. From that reason, according to sor singgih basa Bali, the choice of words that he should use is Basa Bali Alus. It is because the one who is talking to him is older and her position is also higher than him who is his teacher. Moreover, the interaction is occurred in formal situation where it took place in the classroom during the teaching and learning process. So, actually it will be better if the student asked the teacher by saying " $B u$, ring dija nika griyane Mayweather nggih?" (Ma'am, may I know where is the location of Mayweather house?). Then, the sentence" mule kel pesu" (Of course, I will go out) in the second dialogue should be "Nggih, tiang jagi budal pun" (Yes ma'am, I would like to go out). By saying in this way in which it uses Basa Bali Alus will not be contrary to ethical norm. From the findings above which has been analyzed by using several theories as mentioned above, researchers found out that the word 'impolite' was correctly used in the title of the video. It is because it was supported by some evidences, such as the language, the diction, and the way he talked that showed impoliteness based on the theories as mentioned above.

\section{What are the motives of the student asking about the location of Mayweather's house?}

To answer the question above, an analysis by using some theories was conducted. The researchers found that the student in the video was actually doing a prank or joke on his teacher during the learning process. This can be proved by prank theory that has been explained in literature review. Prank is actually done to bring laughter. In the video at 0.12 seconds, the laughter from other students can be heard after the students asked about the location of Mayweather's house. The students was successfully did his prank as he achieved the goal behind the prank itself which is to bring laughter. However, it caused victim since the teacher looked angry as she 
increased her voice and scolded the students towards what he did in the classroom. It can be seen at 0.22 seconds in the video. This characteristic was also suitable with the theory of prank which says prank may cause victim, harm, or damage. This assumption which says that the student was actually doing a prank was also supported by a related news entitled "Bercanda ke Guru di Kelas,Murid di Bali ini Dinilai Rendahkan Guru". The news reported that the student was actually doing a joke or prank towards the teacher. However, the joke turned to be an act of disrespect and bullying towards the teacher which can be seen from the student's language which is considered as impolite as what has been discussed above.

The analysis towards this motive can also be done by considering the imitation theory by Tarde in Roen (2011). He proposed that someone's behavior, attitude, performance, and life style are the results of imitation process. This explains the motive of the student in doing the prank in which he imitated other people's behavior. Before this video drew attention, similar prank video has already been popular and gained public's attention. The prank video which was viral on social media was about two boys asking a grandmother about a popular character on movie named Alex and Tristan. When we pay more attention to both video, it can be seen that both of them have similar pattern. First of all, the pranksters are boys. Second, the victims are women who are not young anymore. Third, both of the videos were about asking certain people who are popular at the time when the prank was conducted. The first one, Alex and Tristan, were very popular characters from a popular movie from about a year ago. The prank video about it was also published a year ago. Meanwhile the second one, Mayweather, is a world famous boxer who has just won a match on last August. As reported by Sindo News, Mayweather becomes viral and many news about him were released. The prank video about Mayweather was published on September 22nd in which Mayweather still became a hot issue at that time as reported by many mass media, such as Tribun News and Sindo News. From the analysis above, it is clearly shown that the student's motive in asking about Mayweather is to do a prank in which it was based on imitating similar case that has happened.

From the above analysis, another motive which still has relation with the above analysis can be seen. The student was clearly imitating other people as he imitated every single details of the prank that has been done by the previous prankster. The previous pranksters have gained public attention, their video became viral, and they gained fame. By imitating those previous pranksters, it can be seen that another motive of the students who asked about Mayweather is to gain fame which has the same motive as the previous prankster. In imitation theory, it is mentioned that someone who imitates are the one who admires and wants to be the same as the one that she or he imitates.

\section{What are the motives behind choosing teacher as the target of student's question?}

Student in SMK Negeri 3 Denpasar was actually doing a prank. However, a question arose about why did the teacher become the target of the prank? According to Blockley in Williams (2016), a criminologist at the University of Derby, he argues that most of pranks are done by men and the victims are the powerless women, as in this case in which a student is a boy and the target of the prank was the teacher that he thought was a powerless woman. Besides, he argues this pattern is real evidence that pranks are the way for the man to show and maintain his dominant position in society which rewards aggressive and domination male behavior, just like in Bali in which male is believed to have more power and dominance. His arguments can be related to the prank case in SMK Negeri 3 Denpasar, in which the student did a prank to show that he has a dominant position in the class rather than the other students. As what Blockley in Williams (2016) argued, the powerless woman in this case is the teacher itself because of her old age.

Blockey added that in doing the prank, the pranksters would show their power and 
control over the victim. They would be so proud and see this as an achievement, because they have power and are able to control other people. Another point explained by Blockey is about the prankster who never thinks that someone they play the trick on as the victim. They would only see them as the object of their achievement. By considering this theory, it leads the student to do that prank and assert his power in front of his friends. Actually, this student did not see his teacher as a victim, whoever she is. However, this student thought that his teacher as an object to achieve his achievement, in this context is a self-esteem, such as the need for recognition from others, status, fame and appreciation from his friends. As explained in the review of related literature, self-esteem needs is one of the stages of hierarchy pyramid, in which people will follow their ego freely based on the desire to get an appreciation from the surroundings. These appreciations can be anything, even an applause or laughter from someone. Those will make them to be more excited to do so. Selfesteem stage in hierarchy theory also has a relation with the action of the student in SMK Negeri 3 Denpasar who did a prank to his teacher. The need for recognition and dominance is shown from the student's attitude supported by the laughter of his friends. This laughter is considered as an appreciation for himself that made him instead of ending the prank, he increasingly played his prank on the teacher. By the appreciation, in this case the laughter from his friends, this student felt that he already gained fame, status, and recognition from his friends. Thus, they thought he already become the dominant student in the class. At the same time, he also indicated that he has a strong power in the class.

Besides, self-actualization needs from hierarchy theory can be the reason behind choosing teacher as the target of his prank. As already explained in literature review that self-actualization needs is the highest stage of hierarchical pyramid after self-esteem needs, in which people will develop their potency to show and prove themselves to other people. Simply, in this case, the student has to show the potency that he has a power in the class by doing a prank to the teacher. This student saw the teacher as someone who has the greatest power in the classroom. This made him thought that if he can do the prank to someone who has the greatest power, so it will be the evidence that indicated he has the greater power than the teacher or even his friends in the classroom. That is why the student in the video did the prank to his teacher and recorded it as evidence that he was really brave and to show his power to his friends.

\section{CONCLUSION}

After analyzing the discourse, the researchers have discovered several conclusions. First of all, researchers agree that the word 'impolite' should be inserted in the title of the video, since there were found several inappropriate words which is used by the student. This finding was supported by the theory of politeness, sor singgih basa Bali and norms theory. Second, several motives of asking the location of Mayweather's house were found, namely doing a prank, imitating other pranksters, and gaining fame. The prank theory and imitation theory were used to support the analysis. Several related news were also used to support the findings. Lastly, researchers found that showing power is the motive behind choosing teacher as the target of the video. The use of prank theory and hierarchy theory supported this finding.

\section{REFERENCES}

Aditya, R. 2016, October 21. 4 Kasus Siswa Kurang Ajar Pada Gurunya, Nomor 2 Malah Berani Berkata Kasar. Retrieved December 1, 2017, from Tribun News: http://style.tribu news.com/2016/10/21/4-kasus-siswa kurang-ajar-pada-gurunya-nomor 2-malah-berani-berkata-kasar?page $=3$ Adnyana, P. 2014. Penguasaan Sor Singgih Bahasa Bali Dalam Keterampilan Berbicara Siswa Kelas IX SMP Negeri 3 Denpasar Tahun Pelajaran 2013/2014. Denpasar. Brown, P., \& Levinson, S. 1987. Politeness: 
Some Universals of Language Use. Cambridge: Cambridge University Press.

Cambridge Dictionary. 2015, July 8. Prank. Retrieved December 1, 2017, from Cambridge Dictionary: http://dictionary.cam bridge.org/dictionary/english/prank.

Faridy, M. 2009. Pendidikan Kewarganegaraan 1. In M. Faridy, Norma-Norma Kehidupan Bermasyarakat, Berbangsa, dan Bernegara (pp. 3-12). Jakarta: Sutra Benta Perkasa

Lisa, W. 2013, September 18. Teori Abraham Maslow. Retrieved December 3, 2017, from http://wardalisa.staff.gunadarma.ac.id/downloads/files/26402/ materi+07+-+TeoriAbrahamMaslow.pdf

Nordquist, R. 2017, March 28. Politeness Strategies in English Grammar. Retrieved December 25, 2017, from ThoughtCo.: http:// www.thoughtco.com/politeness-strategies-conversation-1691516

Oxford Dictionary. Polite. Retrieved December 1, 2017, from Oxxford Dictionary: https://en.oxforddictionaries.com/definition/polite

Psychologypapers. Why Do People Play Practica Jokes? Retrieved December 2, 2017, Psychologypapers: http://www. psychologypapers.org/why-do-peopleplay-practical-jokes.html

Roen, F. 2011, September 21. Gabriel Tarde: Kearah Sumber-Sumber Psikologi Sosial. Retrieved December 1, 2017, from Teori dan Perilaku Organisasi: http://perilakuor ganisasi.com/kearah-sumber-sumberpsikologi-sosial.html

Waruwu, C. 2017, September 22. Brilio.net. Retrieved December 1, 2017, from Bercanda ke Guru di Kelas, Murid di Bali ini Dinilai Rendahkan Guru: https://m.brilio.net/ creator/seorang-guru-dilecehkan-olehmuridnya-sendiri-netizen-geram-092253. html

Williams, L. 2016, November 21. What the Popularity of Prank culture Tells Us About Ourselves. Retrieved Decemmber 1, 2017, from Vice.com: https://goog leweblight.com/?lite_url=https://www. vice.com/sv/article/dpkd3y/ why-are-we-so-obsessed-withscaring-people\&ei $=v f P X j l F \_\& l c=i d-$ $I D \& s=1 \& m=10 \&$ host $=w w w . g o o g l e$. co.id\& ts $=1512359271 \&$ sig $=A N T Y_{-}$ L2YA3mX-8cu3N5X2h1QAPZJfVhXNg 